DOI: $10.4067 / \mathrm{S} 0718-162020150002000014$

\title{
RESEARCH PAPER \\ Potential in vitro degradability and gas production of the byproducts of the biodiesel chain
}

\author{
Aderbal M. de A. Silva1, Simone V. Alves ${ }^{1}$, Leilson R. Bezerra ${ }^{2}$, Heloisa \\ Carneiro $^{3}$, Ronaldo L. Oliveira ${ }^{4}$, Fabíola F. de Medeiros ${ }^{1}$, José M. Pereira \\ Filho', and Dário R. C. de Araújo ${ }^{1}$
}

${ }^{1}$ Federal University of Campina Grande (FUCG), Centro de Saúde e Tecnologia Rural, Patos, Paraíba, CEP. 58708-110, Brazil.

${ }^{2}$ Federal University of Piauí (FUP), Campus Professora Cinobelina Elvas, Bom Jesus city, Piauí State, UFPI, CEP. 64900-000, Brazil.

${ }^{3}$ Embrapa Dairy Cattle, Rua Eugênio do Nascimento, 610, Juiz de Fora, Minas Gerais, CEP. 36038-330, Brazil.

${ }^{4}$ School of Veterinary and Zootecnia/ Federal University of Bahia (FUB), Salvador city, Bahia State, CEP. 40170-110, Brazil.

\begin{abstract}
A.M. de A. Silva, S.V. Alves, L.R. Bezerra, H. Carneiro, R.L. Oliveira, F.F. de Medeiros, J.M. Pereira Filho, and D.R.C. de Araújo. 2015. Potential in vitro degradability and gas production of the byproducts of the biodiesel chain. Cienc. Inv. Agr. 42(2):285-293. The objective of this research was to evaluate the in vitro degradability and gas production from different byproducts of the domestic biodiesel industry (Glycine max, Brassica napus L., Helianthus annuus and Raphanus sativus L.) using four increasing levels (0, 30, 50 and $70 \%$ ) of replacement of Pennisetum purpureum. The inoculum for the in vitro incubations was obtained from three Holstein cows with rumen fistulas. Gas production was measured at 3, 6, 12, 24 and 48 hours of incubation. The experimental design was a completely randomized $4 \times$ 4 factorial arrangement, with byproducts and their levels being the factors. The results showed a significant effect $(\mathrm{P} \leq 0.05)$ of all byproducts. A higher level of degradation was observed following 48 hours of incubation with Glycine max compared with other byproducts, but it did not reduce gas production; Raphanus sativus was the most efficient byproduct to reduce the total gas production. The lowest degradation was obtained with sunflower. All the studied byproducts may be used in the diet of ruminants as potential protein supplements.
\end{abstract}

Key words: Brassica napus L., Helianthus annuus, nutrition, Raphanus sativus $L$, ruminants.

\section{Introduction}

Increasing interest in biodiesel as a replacement for fossil fuels has resulted in oilseeds, which

Received August 6, 2014. Accepted June 30, 2015 Corresponding author: leilson@ufpi.edu.br are suitable for direct human consumption, being used for the production of renewable fuels. Thus, the use of non-traditional grains and oilseeds that do not compete directly with human consumption are becoming attractive alternatives for the production of ethanol and biodiesel, respectively. 
In addition to economic considerations, the introduction of non-conventional foods is driven by characteristics that favor an amelioration in $\mathrm{CH}_{4}$ levels and consequently reduce environmental impacts, as these outcomes are now prerequisites for funded projects that benefit animal production systems and contribute to the development of the various production chains (Moreira et al., 2014). Therefore, decreasing methane production is desirable for reducing greenhouse gas emissions together with providing an improved efficiency of utilization of the digested energy (Johnson and Johnson, 1995).

Brazil has emerged on the world scene as a primary producer of biodiesel due to its great diversity in grains, its sources of vegetable oil, and its extensive use of sheep farming (which provides animal fat and tallow). Thus, the byproducts derived from the biodiesel production chain in Brazil have been studied as potential ingredients for ruminant diets because the use of alternative sources of energy is one of the great current priorities; in addition, the use of these byproducts has contributed significantly to technological developments that overcome serious issues and involves several residues typically underutilized in other production chains (Rodrigues and Rondina, 2013). Studies and techniques that characterize the ruminal metabolism of these byproducts, such as technical in vitro gas production, are indispensable for identifying potential ingredients that may be used efficiently in the diet of ruminants to replace conventional food byproducts.

Thus, a determination of the amount of gas produced in vitro is indicative of food fermentation by microbial digestion; the fermentation residues in the gases include carbon dioxide gas $\left(\mathrm{CO}_{2}\right)$ and methane $\left(\mathrm{CH}_{4}\right)$. The use of gas-production techniques shows many advantages with regard to animal welfare, sample size and cost. The most important aspect is that gas-production techniques describe the kinetics of the activity of microorganisms in response to a given substrate (Mizubuti et al., 2014).
The objective of this study was to evaluate the effects of the levels of byproducts of the biodiesel chain on the degradability and the total gas production in vitro. The byproducts were used to replace the elephant grass in the diet of cattle.

\section{Materials and methods}

This research was conducted at the Experimental Station of Coronel Pacheco, MG, owned by Embrapa Gado de Leite - CNPGL and located in the Coronal Pacheco city, Minas Gerais State, Brazil.

\section{Feeds and substrates}

Four different oilseed press cakes commonly used for biodiesel production were tested in the in sacco study: soybean meal [SBM, Family Fabaceae (alt. Leguminoseae; Glycine max)], canola (Family Brassicaceae; Brassicanapus L), sunflower (Family Asteraceae; Helianthus annuus), and oilseed radish(Family Brassicacea; Raphanus sativus L), with elephant grass (Pennisetum purpureum) used as a control.

The castor oilseed press cakes were purchased from a Brazilian plant located in the municipality of Iraquara (Ecodiesel, Iraquara city, bahia state, Brasil) and transported to Embrapa Semiarid, where they were detoxified using calcium hydroxide $\left[\mathrm{Ca}(\mathrm{OH})_{2}\right]$ diluted in water at a ratio of $9 \mathrm{~L}$ of water kg-1 of $\mathrm{Ca}(\mathrm{OH})_{2}$ at a ratio of $60 \mathrm{~g}$ of $\mathrm{Ca}(\mathrm{OH})_{2} \mathrm{~kg}^{-1}$ castor oilseed press cake. Following this treatment, the castor oilseed press cake was packed into a 200-L polyethylene drum for $24 \mathrm{~h}$ and allowed to dry in the sun for $12 \mathrm{~h}$.

The remaining oilseed press cakes were obtained from Embrapa Dairy Cattle in Juiz de Fora (MG, Brazil). Elephant grass (Pennisetum purpureum; control) was harvested following $60 \mathrm{~d}$ of re-growth at the EMBRAPA Dairy Cattle Research Centre (Coronel Pacheco, MG, Brazil) located at 21 ${ }^{\circ} 35^{\prime}$ $\mathrm{S}, 43^{\circ} 15^{\prime} \mathrm{W}$ and at an elevation of $435 \mathrm{~m}$ above 
sea level. The DM and chemical composition of the oilseed press cake and elephant grass samples were analyzed (Table 1).

\section{In vitro incubations}

Substrates. The substrates used for in vitro incubations were elephant grass (Pennisetum purpureum) supplemented with oilseed press cake in ratios of 70/30, 50/50 and 70/30\% (elephant grass/byproduct) for each treatment. The feed ingredients were dried at $55^{\circ} \mathrm{C}$ for $24 \mathrm{~h}$ and then ground before being passed through a 1-mm mesh screen. Each in vitro incubation was conducted as per Meale et al. (2012). The entire incubation procedure was repeated twice (i.e., two incubation runs $\times$ three replicates per treatment, resulting in a total of six replicate vials per treatment).

Inoculum. The inoculum for the in vitro incubations was obtained from three ruminally fistulated cows grazing beard grass supplemented with $2 \mathrm{~kg}$ of concentrate $\left(22 \mathrm{~g} \mathrm{~kg}^{-1} \mathrm{CP}\right.$ and $12.6 \mathrm{~g} \mathrm{~kg}^{-1} \mathrm{NDF} /$ $\mathrm{kg} \mathrm{DM})$. The rumen fluid was collected $2 \mathrm{~h}$ prior to the morning milking from 4 distinct sites in the rumen and then filtered through 4 layers of cheesecloth; subsequently, equal portions from each animal were combined and immediately transported in a pre-warmed Thermos ${ }^{\circledR}$ flask to the laboratory. The inoculum was prepared by mixing the rumen fluid and a mineral buffer with $0.5 \mathrm{~mL}$ of cysteine sulfide solution (Vitti et al., 1999) at a ratio of 1:5. The inoculum $(30 \mathrm{~mL})$ was then transferred into pre-loaded, pre-warmed $\left(39^{\circ} \mathrm{C}\right)$ vials under a stream of $\mathrm{O}_{2}$-free $\mathrm{N}$ gas. The vials were then sealed and placed on an orbital shaker rack set at 120 oscillations per min in an incubator set at $39^{\circ} \mathrm{C}$.

Determination of the total gas and in vitro drymatter degradability (IVDMD). The net gas production in each vial was measured following $6,12,24$ and $48 \mathrm{~h}$ of incubation using a water displacement apparatus (Fedorak and Hrudey, 1983). At 6 and $12 \mathrm{~h}$ prior to gas measurement, the headspace gas was sampled from each vial using a $20-\mathrm{mL}$ syringe and then immediately transferred into a 5.9-mL evacuated Exetainer ${ }^{\circledR}$ (Labco Ltd., High Wycombe, Buckinghamshire, UK). The ANKOM ${ }^{\circledR}$ bags with the residues were then removed from the bottles, rinsed thoroughly with distilled water, and dried at $55^{\circ} \mathrm{C}$ for $48 \mathrm{~h}$ until reaching a constant weight for estimation of the In vitro Dry Matter Degradability (IVDMD).

\section{Chemical analysis}

The substrates comprising the materials and byproducts were pre-dried in forced-air ovens at 60 ${ }^{\circ} \mathrm{C}$ for $48 \mathrm{~h}$. The substrates were then ground in a Willey mill equipped with a sieve with holes of 1.0 $\mathrm{mm}$ to determine the amount of dry matter (DM) at $105^{\circ} \mathrm{C}$ and crude protein (CP) using the Kjeldahl method according to the general procedures de-

Table 1. Chemical composition $\left(\mathrm{g} \mathrm{kg}^{-1}\right)$ of elephant grass and the four substrates resulting from the industrial production of biodiesel.

\begin{tabular}{lccccccccc}
\hline Ingredients & DM & CP & NDF & ADF & ADL & EE & ASH & TC & IVDMD \\
\hline Elephant grass & 882.3 & 126.1 & 555.0 & 351.1 & 144.4 & 14.2 & 25.4 & 83.43 & 591.4 \\
Byproducts & & & & & & & & & \\
Soybean meal & 869.9 & 528.4 & 184.5 & 106.7 & 15.9 & 18.3 & 66.0 & 38.73 & 808.9 \\
Canola & 922.1 & 375.1 & 410.3 & 378.3 & 120.5 & 24.3 & 57.7 & 54.29 & 689.0 \\
Oilseed radish & 935.6 & 393.7 & 380.5 & 154.2 & 69.6 & 28.4 & 50.6 & 27.16 & 644.8 \\
Sunflower & 901.1 & 342.6 & 390.1 & 243.6 & 34.3 & 32.1 & 54.9 & 57.04 & 582.3 \\
\hline
\end{tabular}

Abbreviations: DM, Dry Matter; CP, Crude Protein; NDF and ADF, Neutral- and Acid-Detergent Fiber; ADL, Acid-Detergent Lignin; EE, Ether Extract; ASH, Ashes; TC, Total Carbohydrates; IVDMD, In vitro Dry Matter Degradability. 
Table 2. Mean values, probabilities (P-value) and regression equations describing in vitro dry matter degradability (IVDMD; \%) of the byproducts from biodiesel production at different levels of substitution for elephant grass following 48 hours of incubation in vitro.

\begin{tabular}{lcccccccc}
\hline & \multicolumn{9}{c}{ Levels of substitution (\%) } & & & \\
\cline { 2 - 5 } Byproduct & 0 & 30 & 50 & 70 & & Regression equations & $\mathrm{R}^{2}$ & $\mathrm{P}$ \\
\hline Soybean meal & 52.935 & $63.413 \mathrm{~A}$ & $65.880 \mathrm{~A}$ & $72.810 \mathrm{~A}$ & $\hat{\mathrm{Y}}=53.53+0.27 \mathrm{x}$ & 0.82 & $0.0001^{*}$ \\
Canola & 52.935 & $56.477 \mathrm{~B}$ & $62.015 \mathrm{~A}$ & $57.892 \mathrm{~B}$ & $\hat{\mathrm{Y}}=-1.915 \mathrm{x}^{2}+11.617 \mathrm{x}+42.645$ & 0.83 & $0.04^{*}$ \\
Oilseed radish & 52.935 & $57.785 \mathrm{AB}$ & $62.658 \mathrm{~A}$ & $58.075 \mathrm{~B}$ & $\hat{\mathrm{Y}}=-2.3575 \mathrm{x}^{2}+13.816 \mathrm{x}+40.997$ & 0.90 & $0.03 *$ \\
Sunflower & 52.935 & $54.058 \mathrm{~B}$ & $55.217 \mathrm{~B}$ & $56.128 \mathrm{~B}$ & $\hat{\mathrm{Y}}=1.073 \mathrm{x}+51.895$ & 0.99 & $0.01 *$ \\
\hline
\end{tabular}

*Means in the same column with different letters differ statistically at a $5 \%$ probability (Tukey test).

scribed by Silva and Queiroz (2002). The amounts of neutral-detergent fiber (NDF) and acid-detergent fiber (ADF) were determined using the Van Soest et al. (1991) method, and ether extracts (EE) were obtained by filtering forage and byproducts in XT4 bags (Ankon) ${ }^{\circledR}$ and subjecting the filtrate to extraction at high temperature using an XT10 extractor (Ankon)®. IVDMD was assessed following the methodology proposed by Tilley and Terry (1963). The amount of total carbohydrates (TC) was obtained using the equation $100-(\% \mathrm{CP}+\%$ $\mathrm{EE}+\%$ ash), as described by Sniffen et al. (1992).

\section{Statistical analyses}

The experimental design used to evaluate the cumulative gas production and the degradability of dry matter was based on a completely randomized $4 \times 4$ factorial arrangement (byproducts and substitution levels). The total gas production and degradability of DM were subjected to analysis of variance (PROC ANOVA) with interaction effects. We applied the Tukey test $(\mathrm{P} \leq 0.05)$ to discriminate the byproducts for within-level substitution effects and within-byproduct substitution effects. The effects of increasing levels of byproduct were interpreted via regression models using the PROC REG command in SAS ${ }^{2}$ (2003).

\section{Results}

An interaction effect among the types of byproducts and replacement levels with regard to in vitro dry-matter degradability was found (IVDMD; $\mathrm{P} \leq 0.05$; Table 2). Analyzing the byproducts according to the replacement levels, it appears that at a level of $30 \%$ replacement of elephant grass, the oilseed radish was the byproduct that showed the most degradation $(\mathrm{P} \leq 0.05)$; however, the level was not different from that of soybean $(\mathrm{P}>0.05)$.

The IVDMD of soybean was $11 \%$ higher than that of the canola byproduct and $15 \%$ higher than the IVDMD of black sunflower. With respect to $50 \%$ substitution, the black sunflower byproduct showed the lowest degradation $(\mathrm{P} \leq 0.05)$, which was $15 \%$ lower than that of soybeans, although not reaching statistical significance $(\mathrm{P} \leq 0.05)$.

At the $70 \%$ level, the black sunflower byproduct did not differ from the canola or wild radish byproducts $(\mathrm{P}>0.05)$; however, all the byproducts tested showed lower degradation than that of soybean $(\mathrm{P} \leq 0.05)$.

The replacement levels of elephant grass within each byproduct influenced the IVDMD significantly $(\mathrm{P} \leq 0.05)$. The soy and black sunflower byproducts showed opposing linear behaviors, with an increase in the percentage of soybean byproduct correlating with an increase of $0.27 \%$ DM degradability, whereas an increase in the black sunflower reduced the degradability by $0.04 \%$.

The canola and oilseed radish byproducts showed quadratic behavior, with a maximum degradability $(61.62 \%)$ at $67.5 \%$ replacement of elephant grass 
with canola and a minimum of $52.45 \%$ degradation at $55 \%$ replacement with oilseed radish.

An interaction effect was noted $(\mathrm{P} \leq 0.05)$ between the levels of the byproducts and the total gas production following $48 \mathrm{~h}$ incubation (Table 3 ).

When assessing the byproducts with respect to the replacement levels, it appears that at the level of $30 \%$ replacement of elephant grass, the canola byproduct showed the greatest gas production $(\mathrm{P} \leq 0.05)$. Similarly, the black sunflower byproduct $(\mathrm{P}>0.05)$ produced approximately $50 \%$ more gas than the soybean or oilseed radish byproducts, which performed similarly $(\mathrm{P}>0.05)$.

At 50\% replacement, the behaviors were similar to those of the $30 \%$ level in that the lowest production was recorded for the oilseed radish byproduct, which performed similarly to soybean $(\mathrm{P}>0.05)$. The oilseed radish byproduct produced $55 \%$ less total air $(\mathrm{P} \leq 0.05)$ when compared with the canola byproduct, which showed the largest production. At $70 \%$ replacement, the oilseed radish byproduct showed significantly lower gas production $(\mathrm{P} \leq 0.05)$ than all other byproducts. At $70 \%$, the soybean byproduct resulted in a total gas production similar $(\mathrm{P}>0.05)$ to that of the black sunflower and canola byproducts.

Regarding the comparisons among the byproducts, the oilseed radish byproduct showed a negative correlation, i.e., with each percentage point increase in levels of oilseed radish, the gas production decreased by $0.15 \mathrm{~mL} \mathrm{~g}^{-1}$.

Gas production from the soy, canola and black sunflower byproducts showed quadratic behavior. For the soybean byproduct, $20.25 \%$ replacement resulted in a minimum of $71.70 \%$ gas production. With respect to the canola byproduct, $40 \%$ replacement caused a peak of $63 \mathrm{~mL} \mathrm{~g}^{-1}$, and the black sunflower byproduct, at $61.5 \%$ replacement, induced a maximum of $67 \mathrm{~mL} \mathrm{~g}^{-1}$ total gas production.

\section{Discussion}

The chemical compositions of the byproducts used for these analyses (Table 1) differ from that of the conventional bran that is currently used in feed; although they include many of the same constituents, the concentrations of these constituents differ, particularly with regard to fibrous material. During ruminal fermentation, when the increase in NDF and EE declines, no corresponding decrease in total gas production is observed. This pattern is based on the stoichiometry of the production of gas, where the quantity of fiber present in the diet promotes an increase in the total gas production (Kozloski, 2009).

Assuming that the average retention time of food in the rumen is 48 hours, the greater the degradation during this period, the higher the quality of food

Table 3. Mean values, probabilities (P-value) and regression equations describing the total gas production ( $\left.\mathrm{mL} \mathrm{g}^{-1}\right)$ from the byproducts of biodiesel production at different levels of substitution for elephant grass following 48 hours of incubation in vitro.

\begin{tabular}{|c|c|c|c|c|c|c|c|}
\hline \multirow[b]{2}{*}{ Byproduct } & \multicolumn{4}{|c|}{ Levels of substitution (\%) } & \multirow[b]{2}{*}{ Regression equations } & \multirow[b]{2}{*}{$\mathrm{R}^{2}$} & \multirow[b]{2}{*}{$\mathrm{P}$} \\
\hline & 0 & 30 & 50 & 70 & & & \\
\hline Soybean meal & 72.1 & $68.3 \mathrm{~B}$ & $96.1 \mathrm{~B}$ & $137.3 \mathrm{~A}$ & $\hat{Y}=71.76+0.81 x-0.02 x^{2}$ & 0.67 & 0.002 \\
\hline Canola & 72.1 & $140.1 \mathrm{~A}$ & $150.1 \mathrm{~A}$ & $145.0 \mathrm{~A}$ & $\hat{Y}=72.64+3.04 x-0.02 x^{2}$ & 0.96 & 0.0001 \\
\hline Oilseed radish & 72.1 & $66.3 \mathrm{~B}$ & $67.2 \mathrm{~B}$ & $59.72 \mathrm{~B}$ & $\hat{Y}=75.39-3.624 x$ & 0.84 & 0.005 \\
\hline Sunflower & 72.1 & $129.6 \mathrm{~A}$ & $132.5 \mathrm{~A}$ & $131.4 \mathrm{~A}$ & $\hat{Y}=73.05+2.46 x-0.02 x^{2}$ & 0.96 & 0.0001 \\
\hline
\end{tabular}

*Means in the same column with different letters differ significantly at a 5\% probability (Tukey test). 
fermentation (Faciola and Broderick, 2013). In Table 2, the soybean byproduct is found to exhibit the highest degradability, and $70 \%$ replacement of elephant grass with soybean residue is found to promote degradation, which may be attributed to the lower levels of the NDF $\left(184.5 \mathrm{~g} \mathrm{~kg}^{-1}\right)$ and the EE $\left(18.3 \mathrm{~g} \mathrm{~kg}^{-1}\right)$ and the higher protein concentration (Table 1). The degradability of this byproduct suggests that the soybean byproduct induces improved rumen fermentation relative to the other byproducts studied. The black sunflower byproduct showed the lowest rate of increase in degradation per percentage point increase in the replacement level, which may be explained by this byproduct's high fiber (390.1 $\left.\mathrm{g} \mathrm{kg}^{-1}\right)$ and lignin (34. $3 \mathrm{~g} \mathrm{~kg}^{-1}$ ) content. The presence of large amounts of phenolic compounds, such as lignin, causes an increase in the indigestible fraction of the food and reduces the potentially digestible fraction, which greatly reduces the performance of the animals (Mizubuti et al., 2011; Belachew et al., 2013; Gonzaga Neto et al., 2013). In contrast, foods that do not contain these phenolic substances or where they are present at low levels, as in most oilseeds, help mitigate greenhouse gases and show more rapid degradation, which also contributes to the growth of ruminal microorganisms. However, despite these advantages, protein may be lost as ammonium when energy levels in the diet are insufficient (Pablo-Pérez et al., 2014; Oliveira et al., 2015).

Knowing that gas production is directly associated with diet, microbial fermentation and rumen degradability following $48 \mathrm{~h}$ of incubation, all levels of substitution of the canola byproduct for elephant grass promoted greater cumulative gas production, and no between-level differences were observed, which may be explained by the higher NDF content of canola. Cellulolytic bacteria and the combination of cellulolytic and hemicellulolytic bacteria actively ferment structural carbohydrates and degrade them into cellulose and hemicellulose via the cellulase enzyme, thereby producing cellobiose, the levels of which decline due to further degradation by these microorganisms, which finally generate maltose. The degradation of maltose via succinate results primarily in the production of acetate, $\mathrm{CO}_{2}$ and hydrogen, contributing to greater gas production. This process wastes a considerable amount of energy, with $300 \mathrm{~L}$ of $\mathrm{CO}_{2}$ and $\mathrm{CH}_{4}$ produced for every 4,000 kcal of energy produced. However, this process is of fundamental importance because higher fiber concentrations result in longer retention times for food in the rumen and increased salivation, which assist in the maintenance of rumen $\mathrm{pH}$ and the maintenance of ruminal microflora (Belanche et al., 2012).

Of all the byproducts tested in the present study, the one that most resembles the degradability of soybean and total gas production at all levels of substitution was the oilseed radish byproduct. The low total-air volume observed for the oilseed radish byproduct at $70 \%$ replacement of elephant grass may be due to the high EE concentration in this byproduct. The high energy value of fats, which provide 2.25 -fold more energy than carbohydrates or proteins, constitute the primary attraction for their use in feed, and they increase food efficiency remarkably (Ivan et al., 2013; Morais et al., 2015). However, the convenience of adding fat as a source of metabolizable energy contrasts with its deleterious effects on rumen microorganisms, which in turn become a limiting factor.

When fat levels exceed 5 to $7 \%$ of the diet, or when the diet is rich in unsaturated fatty acids, digestive disorders involving reduced consumption may occur. In addition, high fat levels in the rumen in the case of a shortage of emulsifier (bile) and enzymes, such as lipase, interfere with the digestive process by coating the contents of the rumen, particularly when digesting fiber. In addition, because of a linear decrease in their weight gain and body weight, animals may be lighter at the time of slaughter and housing costs may therefore be lower (Silva et al, 2013; Xin and Yu, 2013).

The highest gas production levels observed with the byproducts of black sunflower, canola and soy at $70 \%$ replacement were due to the degradation of fibrous carbohydrates. Thus, 
this fraction shows good rumen fermentation, depending on the balance between energy and nitrogen compounds supplied to the ruminal microfauna, and enhances the degradation of the fiber from food. According to Getachew et al. (2004), the volume of gas produced following food incubation reflects the production of shortchain fatty acids, which are the main source of energy for the ruminants.

In the presence of oilseed byproducts, 3 to $5 \%$ of the microbial biomass in the rumen produces $\mathrm{CH}_{4}$. The reaction is as follows: $\mathrm{CO}_{2}+4 \mathrm{H}_{2}=\mathrm{CH}_{4}$ $+2 \mathrm{H}_{2} \mathrm{O}$. Furthermore, methane may also be produced, albeit at a small scale, from other reactions, including the reduction of formic acid, methanol, methylamine, diethylamine, and triethylamine (Morgavi et al., 2010; Morgavi et al., 2012). The process of methanogenesis and the amount of $\mathrm{CH}_{4}$ gas in the rumen correlate directly with the population of micro-organisms and the health of this population. The addition of appropriate levels of byproducts containing high amounts of fat should not impair the microbial flora or reduce the benefit of these reactions (Cieslak et al., 2013; Medeiros et al., 2015).

The canola byproduct resulted in enhanced availability of nutrients for the growth of ru- men microorganisms in vitro, with a maximum increase observed at $76 \%$ replacement, which produced $63.40 \mathrm{~mL}$ of total gas (Xin and $\mathrm{Yu}$, 2013).

The soybean byproduct at $70 \%$ replacement for elephant grass resulted in the best rumen fermentation kinetics and promoted greater degradation; however, a higher amount of total gas was observed relative to the other byproducts studied. The oilseed radish byproduct at $70 \%$ replacement mitigated the total gas production, which is beneficial because it meets the overall objective of reducing greenhouse gases. All byproducts are potential suppliers of protein in cattle feed; however, further studies are required on the effect of the concentration of ether extract present in these byproducts to assess whether it may compromise performance or animal welfare.

\section{Acknowledgements}

The authors thank the Conselho Nacional de Desenvolvimento Científico e Tecnológico (CNPq), Embrapa Dairy Cattle, and Fundação de Amparo a Pesquisa do Estado de Minas Gerais (FAPEMIG), Brazil.

\title{
Resumen
}

\begin{abstract}
A.M. de A. Silva, S.V. Alves, L.R. Bezerra, H. Carneiro, R.L. Oliveira, F.F. de Medeiros, J.M. Pereira Filho y D.R.C. de Araújo. 2015. Potencial de degradabilidad y producción de gas in vitro de subproductos de la cadena de biodiesel. Cienc. Inv. Agr. 42(2):285-293. El objetivo de esta investigación fue evaluar la producción de gas y degradabilidad, mediante técnica in vitro de diferentes subproductos para la industria nacional de biodiesel (Glycine max, Brassica napus L., Helianthus annus y Raphanus sativus L.), en cuatro niveles (0, 30, 50 y $70 \%$ ) sustitución de Pennisetum purpureum. El inóculo para la incubación in vitro se obtuvo de tres vacas Holstein con fístulas del rumen. La producción de gas se midió 3, 6, 12 , 24 y 48 horas después de la incubación. El diseño experimental fue completamente al azar en un arreglo factorial $4 \times 4$, con los factores que representan los subproductos y niveles. De acuerdo con los resultados de todos los subproductos estudiados mostraron un efecto significativo $(\mathrm{P} \leq 0,05)$ por las dietas. Glycine max en 48 horas de incubación fue el subproducto que mostró una mayor degradación, en comparación con los demás, pero no redujo la producción de gas, siendo el Raphanus sativus como subproducto eficiente para reducir la producción total de gas. Todos
\end{abstract}


los subproductos estudiados pueden ser utilizados en la dieta de los rumiantes, como posibles suplementos de proteínas.

Palabras clave: Brassica napus L., Helianthus annuus, nutrición, Raphanus sativus L., ruminantes.

\section{References}

Belanche, A., G. de la J.M. FuenteMoorby, and C.J. Newbold. 2012. Bacterial protein degradation by different rumen protozoal groups. Journal Animal Science 90:4495-4504.

Belachew, Z., K. Yisehak, T. Taye, and G.P.J. Janssens. 2013. Chemical composition and in sacco ruminal degradation of tropical trees rich in condensed tannins. Czech Journal Animal Science 58:176-192.

Cieslak, A., M. Szumacher-Strabel, A. Stochmal, and W. Oleszek. 2013. Plant components with specific activities against rumen methano-gens. The Animal Consortium 7:253-265.

Faciola, A.P., and G.A. Broderick. 2013. Effects of feeding lauric acid on ruminal protozoa numbers, fermentation, and digestion and on milk production in dairy cows. Journal Animal Science 91:2243-2253.

Fedorak, P.M., and S.E. Hrudey. 1983. A simple apparatus for measuring gas-production by methanogenic cultures in serum bottles. Environ. Technology Lett 4:425-432.

Getachew, G., P.H. Robinson, E.J. De Peters, and S.J. Taylor. 2004. Relationship between chemical composition, dry matter degradation and in vitro gas production of several ruminant feeds. Animal Feed Science and Technology 111(1-4):57-71.

Gonzaga Neto, S, R.L. Oliveira, F.H. Lima, A.N. Medeiros, L.R. Bezerra, J. Viégas, N.G. Nascimento Jr, and M.D. Freitas Neto. 2015. Milk production, intake, digestion, blood parameters, and ingestive behavior of cows supplemented with by-products from the biodiesel industry. Tropical Animal Health Production 47:191-200.

Ivan, M., H.V. Petit, J. Chiquette and A.D.G. Wright. 2013. Rumen fermentation and microbial population in lactating dairy cows receiving diets con- taining oilseeds rich in C-18 fatty acids. British Journal of Nutrition 109:1211-1218.

Johnson, K.A., and D.E. Johnson. 1995. Methane emissions from cattle, Journal of Animal Science 73:2483-2492.

Kozloski, G.V. 2009. Bioquímica dos ruminantes. Editora da UFSM, Santa Maria, 2 ${ }^{\text {nd }}$ Edition. 216 pp.

Meale, S.J., A.V. Chaves, J. Baah, and T.A. Mcallister. 2012. Methane production of different forages in in vitro ruminal fermentation. Asian Australasian Journal Animal Science 25:86-91.

Medeiros, F.F., A.M.A. Silva, H. Carneiro, D.R.C. Araújo, R.K.O. Morais, M.N. Moreira, and L.R. Bezerra. 2015. Alternative protein sources derived from the biodiesel production chain for feeding to ruminants. Arquivos Brasileiro de Medicina Veterinária e Zootecnia 67:519-526.

Mizubuti I.Y., E.L.A Ribeiro, E.S. Pereira, E.L.T. Peixoto, E.S. Moura, O.P.P. Prado, V.H. Bumbieris Junior, L.D.F. Silva, and J.M.C. Cruz. 2014. Ruminal degradation kinetics of protein foods by in vitro gas production technique. Semina: Ciências Agrárias 35:555-566.

Mizubuti, I.Y., E.L.A. Ribeiro, and E.S. Pereira. 2011. Cinética de fermentação ruminal in vitro de alguns coprodutos gerados na cadeia do biodiesel pela técnica de produção de gás. Semina: Ciências Agrárias 32:2021-2028.

Morais, R.K.O., A.M.A. Silva, L.R. Bezerra, H. Carneiro, M.N. Moreira, and F.F. Medeiros. 2015. In vitro degradation and total gas production of byproducts generated in the biodiesel production chain. Acta Scientiarum. Animal Sciences 37:143-148.

Moreira, M.N., A.M.A. Silva, H. Carneiro, L.R. Bezerra, R.K.O. Morais, and F.F. Medeiros. 2014. In vitro degradability and total gas production of biodiesel chain byproducts used as a replacement 
for cane sugar feed. Acta Scientiarum. Animal Sciences 36:399-403.

Morgavi, D.P., C. Martin, J.P. Jouany, and M.J. Ranilla. 2012. Rumen protozoa and methanogenesis: not a simple cause-effect relationship. British Journal of Nutrition 107:388-397.

Morgavi, D.P., E. Forano, C. Martin, and C.J. Newbold. 2010. Microbial ecosystem and methanogenesis in ruminants. Animal 4:1024-1036.

Oliveira, R.L., A.D. Palmieri, S.T. Carvalho, A.G. Leão, C.L. Abreu, C.V.DM. Ribeiro, E.S. Pereira, G.G.P. Carvalho, and L.R. Bezerra. 2015. Commercial cuts and chemical and sensory attributes of meat from crossbred Boer goats fed sunflower cake-based diets. Animal Science Journal 86:557-562.

Pablo-Pérez, M., L.C. Lagunes-Espinoza, J. RamosJuárez, J. López-Upton, E.M. Aranda-Ibáñez, and L. Vargas-Villamil. 2014. Ruminal degradation of aerial biomass and seeds of wild species of Lupinus. Ciencia e Investigación Agraria 41:5-12.

Rodrigues, F.V., and D. Rondina. 2013. An alternative use of bio-diesel sub-products as feed ingredients for ruminants: the crude glycerin. Acta Veterinaria Brasilica 7:91-99.

Silva E.C., M.A. Ferreira, A.S.C. Véras, S.V. Bispo, M.G. Conceição, M.C.B. Siqueira, L.E. Salla, and A.R.D.L. Souza. 2013. Replacement of corn meal by corn germ meal in lamb diets. Pesquisa Agropecuária Brasileira 48:442-449.
Silva, D.J., and A.C. Queiroz. 2002. Análise de alimentos: métodos químicos e biológicos. Editora UFV, $2^{\text {nd }}$ Edition, Viçosa, Minas Gerais, Brazil. $235 \mathrm{pp}$.

Sniffen, C.J., J.D. O'connor, P.J. Van soest, D.G. Fox, and L.J.B. Russel. 1992. A net carbohydrate and protein system for evaluating cattle diets. II. Carbohydrate and protein availability. Journal of Animal Science 70:3562-3577.

Tilley, J.M.A., and R.A. Terry. 1963. A two stage techinique for the in vitro degradability of forage crops. Journal of the British Grassland Society 18:104-111.

Van Soest, P.J., J. Robertson, and B. Lewis. 1991. Methods for dietary fiber, neutral detergent fiber and non-starch polysaccharides in relation to animal nutrition. Journal of Dairy Science 74:35833597.

Vitti, D.M.S., A.L. Abdalla, J.C. Silva filho, N.L.D. Mastro, R. Mauricio, E. Owen, and F. Mould. 1999. Misleading relationships between in situ rumen dry mater disappearance, chemical analyzed and in vitro gas production and degradability, of sugarcane baggage treated with varying levels of electron irradiation and ammonia. Animal Feed Science and Technology 79:145-153.

Xin, H., and P. Yu. 2013. Chemical profile, energy values, and protein molecular structure characteristics of biofuel/bio-oil byproducts (carinata meal) in comparison with canola meal. Journal Agricultural and Food Chemistry 61:3926-3933. 
